\title{
Caste and Provision of Public Goods in India
}

\author{
Raghunath Prasad Saket
}

\begin{abstract}
The empirical regression results, on the basis of latest data show that even after controlling the effect for other control variables, the public expenditure on education and health was negatively correlated with the population of SC/ST. Consequently, the basic infrastructure (like pucca building, number of classrooms, laboratory for students and teachers and boundary wall in school premises) and facilities (like drinking water, urinal, playground, electricity, computer, medical check-up of students) in schools were negatively correlated with the population of SC/ST. Similarly, in health, the basic infrastructure (like availability of sub-centres, primary health centres and community health centres) and facilities (like electricity, water supply, telephone connections, computer, operation theatre, number of beds to admit patients) in public health institutions were negatively correlated with the population of SC/ST. The availability of general infrastructure (road and national highway in $\mathbf{1 0 0}$ square kilometres), and basic amenities in house premises (drinking water and sanitation) were also negatively correlated with the population of SC/ST.
\end{abstract}

Index Terms - India, caste discrimination, population of scheduled castes (SCs)/ scheduled tribes (STs), public expenditure and provision of public goods.

\section{INTRODUCTION}

The Nobel Laureate in Economics Prof. Amartya Sen observed that "unlike other developed countries like USA, UK and Japan, India is trying to become a global economic power with an illiterate and unhealthy labour force. Further he compares the healthcare in India and China and concludes that between 1980 and 2004 China performed better and under democratic system it is difficult to bring any change in India" [1]. Whereas, his counterparts have found that social heterogeneity explains the policy differences adopted by a particular country/ or group of countries [2]. Further, another study provides evidence for lower provision of public goods in ethnically diversified regions of USA [3]. Therefore, huge social heterogeneity in India (division of society into thousands of castes and subcastes) may help to explain poor provision of key public goods like education and health. SCs and STs in India have suffered discrimination and deprivation for centuries, therefore, it is assumed that population of SC/ST may be negatively correlated with provision of public goods.

The paper is organized into five sections. Section second, presents the review on existing literature. Section third, deals with constitutional provision for SCs and STs in education and health. Section fourth, presents method, data sources and empirical results on caste discrimination in public expenditure and in provision of public goods. Section

Manuscript received September 24, 2017; revised November 29, 2017.

Raghunath Prasad Saket is with the Satyawati College, University of Delhi, New Delhi, India (e-mail: raghunathjnu@gmail.com). fifth concludes.

\section{LITERATURE REVIEW}

Although, the constitution of India under article 15 prohibits discrimination on the basis of religion, race, caste, sex, place of birth and any of them [4]. However, despite constitutional prohibition, large number of empirical studies show caste based discrimination against SCs and STs in multiple spheres, for modern democratic India. Caste discrimination and prejudice against them in democratic India is combined in to three groups, which are described below.

\section{A. Caste Discrimination in Education}

In 2001, the supreme court of India ordered all states to provide free cooked meals to all primary school children. The scheme is known as mid- day meal (MDM). Dreze (2003) found complete exclusion for SCs as cook and helper in almost $60 \%$ of sample villages [5]. Another study found four types of discrimination. First, if cook was from low castes (SCs/STs) high castes children refused to eat food. Second, SCs and STs Children were required to sit separately, third and fourth, though was less prevalent, about $9 \%$ villages reported that separate food was cooked and food was inferior or insufficient [6]. Similarly, it was found that SCs and STs Students face discrimination in access to drinking water, in sitting in classrooms, the teachers and fellow students also did not cooperate and behave nicely [7]. Therefore, even after controlling for school attendance, education level and income of the parents, low learning was found for SCs and STs Children as against learning for high castes children [8]. Thus, the educational institutions which are supposed to play their role as an agent of social change are not free from caste prejudices.

\section{B. Caste Discrimination in Health}

The study investigated the effect of caste on health outcomes in India and included four variables to test his hypothesis. These are, first, average age at death, second, health status of elderly people, third, status of treatment, those who are ill and fourth, prenatal and postnatal care. After controlling for the effect of other variables, he found that average age at death was about 5 and 7 years lower for STs and SCs respectively. Similarly, poor health for elderly was 2.6 points higher for SCs when compared with comparable figures for others. Further, elderly among SCs and STs those were suffering from illness were less likely to take treatment respectively by 9.0 and 10.6 points. And SCs and STs Women were less likely to receive pre and postnatal care when compared with high castes women [9]. Likewise, another study show that $97 \%$ SCs children suffer from untouchability, as pharmacists do not touch them 
while dispensing medicine. And $91 \%$ and $87 \%$ children reported that Lab technician make them wait more and do not speak gently respectively. Similarly, more than $90 \%$ children reported that local level health visitor, do not enter the house, spend less time and do not touch while dispensing medicines [10]. The recent study provides more insight- SCs children comparatively suffer more discrimination where health workers are from high castes [11].

\section{Caste and Economic Discrimination}

The study examined per acre yield of high castes and low castes farmers and found higher yield for low castes (SCs and STs) farmers in low caste dominated villages; and lower yield in high castes dominated villages. The author observed that high castes household (mostly the owner of water) did not easily trade water with low castes farmers, which negatively affect yield [12]. Another study enquired the caste gap in net farm income per acre of land cultivated, and found that between 3 and $13 \%$ of income inequality between low and high caste farmers was due to caste bias. Discrimination against SC/ST farmers in access to tube wells, electricity, markets for selling produce were major causes of inter caste inequality in income [13]. Though, most of the SCs are landless labourers in rural India [14]. Further, among them those can afford to buy land; faced discrimination in buying land for agriculture and for building houses [15]. Another study estimated earning differences between SC/ST and Non-SC/ST workers for urban India. The large part of earning differences (85\%) was due to differences in human capital endowment between SC/ST and Non-SC/ST; however, 15\% earning differences was contributed by caste discrimination against SC/ST workers [16]. Similarly, it was found that equally qualified SC/ST and Muslims had 33\% and 67\% less chances of getting call for interview respectively than that of nonSC/ST/OBC groups [17]. In addition to this, study show wide spread employment and wage discrimination against SCs for rural India too [18]. These groups also suffer from caste discrimination in social, religious and political spheres [19]-[23].

Although, literature on caste shed light on wide spread caste discrimination, against SCs and STs, for modern democratic India. However, existing literature do not investigate the relationship between population of SC/ST and provision of public goods. Whereas lower provision of public goods may itself perpetuate vicious circle among them [3]. Therefore, present paper is an attempt to investigate relationship between population of SC/ST and provision of public goods across states in India. The paper may contribute to literature by providing an alternate explanation for higher deprivation of SCs/STs in modern
India.

\section{III.THE CONSTITUTIONAL PROVISIONS FOR SCS AND STS IN INDIA}

Many provisions have been made in the constitution of India to promote the level of development among SCs and STs and to protect them from social exploitation/injustices. Article 14 of constitution of India guarantees equality before law. The article 17 abolishes the practice of untouchability. Article 21a makes provision for free and compulsory education for all children in the age group of six to fourteen. Article 46 makes provision to promote the educational and economic interest of SCs and STs, and protect them from all forms of exploitation. Article 330 provides reservation for them in parliament and state assemblies and article 335 reserves seat in government services [4].

\section{METHOD AND DATA}

To measure the effect of caste (population of SC/ST) on provision of public goods across states in India, ordinary least square multiple regression is used. To control for the effect of other factors, some control variables (like income per capita, size of state in square kilometres, distance of state from national capital and access to sea) are used. 11 states (which altogether consist less than $7 \%$ of total population) are categorised as special category states for the purpose of union transfer. In addition to this, data on per capita income is not available for two tiny states. Therefore out of 35 states and UTs, regression results are based on 22 states which altogether constitute more than $93 \%$ of total India's population [24]. Latest data from The Ministry of Human Resource Development [25], The Central Bureau of Health Intelligence, the Government of India [26], All India School Education Survey, hereafter AISES [27], the National University of Educational planning and Administration (NUEPA) [28], the National Family Health Survey (NFHS) [29], Rural Health Mission (RHM) [30], The Ministry of Road Transport and Highway [31] and census of India [24], are used for regression analysis. All data are available online.

\section{A. Empirical Results- Public Expenditure on Education and Health}

Even after controlling the effect for income and other control variables, per person and per student expenditure on education, and per person expenditure on health, was negatively correlated with the population of SC/ST (table I). For description of variables and descriptive statistics, see Appendix table V and VI.

TABLE I: SUMmARY TABLE OF REGRESSION RESUlTS ON PUBlic EXPENDITURE ON EDUCATION AND HEALTH

\begin{tabular}{|c|c|c|c|c|c|c|c|c|}
\hline \multirow[t]{2}{*}{ S1. No. } & \multirow{2}{*}{$\begin{array}{l}\text { Dependent } \\
\text { variables }\end{array}$} & \multicolumn{7}{|c|}{ Independent variables } \\
\hline & & Pop SC/ST & Income & Size km2 & Distance & $\begin{array}{l}\text { Access to } \\
\text { sea }\end{array}$ & R-square & Obs. \\
\hline 1 & 2 & 3 & 4 & 5 & 6 & 7 & 8 & 9 \\
\hline \multicolumn{9}{|c|}{ Public expenditure on education } \\
\hline 2 & Exp. as \% of & $-0.03(0.034)$ & $-0.01(0.01)$ & 0.003 & $0.001^{*}$ & $-1.1(1.00)$ & 0.44 & 22 \\
\hline
\end{tabular}




\begin{tabular}{|c|c|c|c|c|c|c|c|c|}
\hline & SGDP & & & $(0.003)$ & $(0.001)$ & & & \\
\hline 3 & Per person exp. & $\begin{array}{l}-15.4 \\
(10.796)\end{array}$ & $8.21 * *(2.994)$ & $\begin{array}{l}-0.2 \\
(1.104)\end{array}$ & $\begin{array}{l}0.5 * * \\
(0.170)\end{array}$ & $\begin{array}{l}-278.6 \\
(303.1\end{array}$ & 0.71 & 22 \\
\hline 4 & Per student exp. & $\begin{array}{l}-19.3 \\
(16.370)\end{array}$ & $11.0 * *(4.541)$ & $\begin{array}{l}-0.34 \\
(1.674)\end{array}$ & $\begin{array}{l}0.63 * * \\
(0.258)\end{array}$ & $\begin{array}{l}-291.1 \\
(460.0)\end{array}$ & 0.67 & 22 \\
\hline \multicolumn{9}{|c|}{ Expenditure on health } \\
\hline 2 & $\begin{array}{l}\text { Exp. as } \% \text { of } \\
\text { SGDP }\end{array}$ & $-0.03(0.019)$ & $-0.001(0.005)$ & $\begin{array}{l}-0.0004 \\
(0.0017) \\
\end{array}$ & $\begin{array}{l}0.0004 \\
(0.0003)\end{array}$ & $\begin{array}{l}-0.4 \\
(0.489)\end{array}$ & 0.39 & 22 \\
\hline 3 & Per person exp. & $-23.3(18.14)$ & $8.3(5.084)$ & $-0.7(1.72)$ & $0.43(0.286)$ & $\begin{array}{l}-228.3 \\
(472.5)\end{array}$ & 0.58 & 22 \\
\hline
\end{tabular}

$* * * 1 \%$ level significance, $* * 5 \%$ level significance, $* 10 \%$ level significance, Data in parenthesis show standard error.

\section{B. Empirical Results on Provision of Public}

goods- The regression results on the basis of data from AISES for 2009-10, for all schools (primary, upper primary, secondary and higher secondary taken together) show negative correlation between infrastructure and basic facilities in school (like number of classrooms, availability of laboratory for students' and for teachers', boundary wall in school premises, drinking water, playground, electricity, urinal for students' and separate urinal for girls') and the population of SC/ST (Table II). The different data sources show similar negative relationship between population of SC/ST and infrastructure and basic facilities in schools. Further, the pattern of negative correlation was similar for different grades of schools. Description of variables and descriptive statistics for table II, III and IV are available with the author.

TABLE II: SUMMARY TABLE OF REGRESSION RESUlTS ON INFRASTRUCTURE AND FACILITIES IN SCHOOL, ALL SCHOOLS.

\begin{tabular}{|c|c|c|c|c|c|c|c|}
\hline \multicolumn{8}{|l|}{ AISES 2009-10 } \\
\hline \multirow[t]{2}{*}{ Dependent variables } & \multicolumn{7}{|c|}{ Independent variables } \\
\hline & Pop SC/ST & Income & Size km2 & Distance & Access to sea & R-square & Obs. \\
\hline Pucca Building & $0.20(0.210)$ & $9.07(7.23)$ & $0.009(0.020)$ & $-0.005(0.003)$ & $5.81(5.295)$ & 0.39 & 22 \\
\hline $\begin{array}{l}\text { Laboratory for } \\
\text { students }\end{array}$ & $-0.20(0.453)$ & $\begin{array}{l}0.0002 \\
(0.0002)\end{array}$ & $-0.008(0.043)$ & $-0.016 * *(0.007)$ & $\begin{array}{l}23.43^{*} \\
(11.42)\end{array}$ & 0.53 & 22 \\
\hline $\begin{array}{l}\text { Laboratory for } \\
\text { teachers }\end{array}$ & $-0.48(0.558)$ & $0.0003 *(0.0002)$ & $-0.05(0.053)$ & $-0.01)(0.008)$ & $7.76(14.05)$ & 0.61 & 22 \\
\hline Boundary-wall & $-0.59(0.495)$ & $0.0003 *(0.0002)$ & $-0.04(0.048)$ & $-0.02 * *(0.007)$ & $16.14(12.47)$ & 0.70 & 22 \\
\hline Drinking water & $\begin{array}{l}-0.33 * \\
(0.176)\end{array}$ & $4.2(6.05)$ & $-0.005(0.017)$ & $-0.003(0.003)$ & $1.04(4.434)$ & 0.45 & 22 \\
\hline Playground & $-0.75(0.468)$ & $0.0003(0.0002)$ & $0.017(0.045)$ & $-0.008(0.007)$ & $7.07(11.795)$ & 0.55 & 22 \\
\hline Electricity & $-0.91(0.642)$ & $0.0006 * *(0.0002)$ & $0.009(0.062)$ & $-0.009(0.009)$ & $23.7(16.17$ & 0.72 & 22 \\
\hline Urinal for students' & $\begin{array}{l}-0.011 \\
(0.449) \\
\end{array}$ & $0.0002(0.0002)$ & $0.02(0.043)$ & $-0.008(0.007)$ & $\begin{array}{l}13.31 \\
(11.324)\end{array}$ & 0.37 & 22 \\
\hline $\begin{array}{l}\text { Separate Urinal for } \\
\text { Girls' }\end{array}$ & $-0.21(0.508)$ & $0.0002(0.0002)$ & $0.02(0.049)$ & $-0.007(0.007)$ & $\begin{array}{l}10.13 \\
(12.799)\end{array}$ & 0.34 & 22 \\
\hline Medical-check-up & $0.42(0.741)$ & $0.0007 * * *(0.0003)$ & $0.12(0.071)$ & $0.007(0.011)$ & $-9.54(18.66)$ & 0.41 & 22 \\
\hline $\begin{array}{l}\text { Frequency of medical } \\
\text { check-up }\end{array}$ & $0.20(0.359)$ & $0.0002(0.0001)$ & $0.01(0.034)$ & $-0.005(0.005)$ & $-6.58(9.05)$ & 0.45 & 22 \\
\hline Vaccination & $0.56(0.744)$ & $0.0006 * *(0.0003)$ & $0.098(0.071)$ & $0.02(0.01)$ & $-6.7(18.72)$ & 0.36 & 22 \\
\hline
\end{tabular}

$1 \%$ level significance, $* * 5 \%$ level significance, $* 10 \%$ level significance, Data in parenthesis show standard error.

The Sub-centres (SCs) are the first contact point in rural India (similar to GP in UK system), and Primary health centres (PHCs) are referral unit working between SCs and community health centres (CHCs). The regression results on health show that even after controlling the effect for other control variables, availability of SCs and PHCs, within 3 kilometres and 10 kilometres respectively, were negatively correlated with the population of SC/ST. Further, except one variable, (SCs without all- weather road) negative variables of health infrastructures (like sub-centres without electricity and sub-centres without water supply), were positively correlated with the population of SC/ST. At PHCs level too, the negative variables of health infrastructure (like PHCs without water and PHCs without electricity) were positively correlated with the population of SC/ST. Whereas, the positive variables (like $\mathrm{PHCs}$ with telephone, Computer, referral transport, operation theatre, and PHCs with at least 4 beds to admit patient), were negatively correlated with the population of SC/ST (table III). The poor infrastructure and facilities in SC/ST dominated region/ states was not limited to education and health. The availability of general infrastructure (like road and national highway in 100 square kilometres), drinking water and tap water, and sanitation in house premises (availability of latrine and drainage) was also negatively correlated with the population of SC/ST (table IV). 
TABLE III: SUMMARY TABLE OF REGRESSION RESULTS ON HEALTH INFRASTRUCTURE AND FACILITIES

\begin{tabular}{|c|c|c|c|c|c|c|c|}
\hline \multicolumn{8}{|l|}{ Sub-centres (SCs) } \\
\hline \multirow[t]{2}{*}{ Dependent variables } & \multicolumn{7}{|c|}{ Independent variables } \\
\hline & Pop SC/ST & Income & Size km2 & Distance & Access to sea & R-square & Obs. \\
\hline Sub centres within $3 \mathrm{KM}$ & $-0.58(0.387)$ & $-0.17(0.08)$ & $-0.09(0.032)$ & $-0.004(0.006)$ & $8.43(9.85)$ & 0.46 & 22 \\
\hline $\begin{array}{l}\text { Sub-centres without all-weather } \\
\text { road }\end{array}$ & $-0.07(0.20)$ & $-0.08 *(0.02)$ & $0.008(0.02)$ & $0.003(0.003)$ & $-11.07 * *(5.20)$ & 0.57 & 22 \\
\hline Sub-centres without water & $0.41(0.46)$ & $-0.18 *(0.10)$ & $-0.002(0.04)$ & $0.003(0.007)$ & $-15.60(11.87)$ & 0.56 & 22 \\
\hline Sub-centres without electricity & $0.23(0.50)$ & $-0.28 * *(0.11)$ & $-0.04(0.05)$ & $0.0003(0.008)$ & $-14.58(12.91)$ & 0.59 & 22 \\
\hline \multicolumn{8}{|l|}{ Primary health centres (PHCs) } \\
\hline PHCs within $10 \mathrm{KM}$ & $-0.42(0.34)$ & $-0.08(0.07)$ & $-0.06(0.03)$ & $\begin{array}{l}-0.001 \\
(0.005)\end{array}$ & $14.63(8.65)$ & 0.51 & 22 \\
\hline PHC without all-weather road & $-0.42 *(0.28)$ & $-0.08(0.06)$ & $0.009(0.02)$ & $\begin{array}{l}0.004 \\
(0.0040\end{array}$ & $-7.13(6.71)$ & 0.35 & 21 \\
\hline PHCs without water & $0.79 * *(0.30)$ & $-0.05(0.07)$ & $-0.03(0.03)$ & $\begin{array}{l}0.004 \\
(0.004)\end{array}$ & $-5.63(7.04)$ & 0.57 & 21 \\
\hline PHC without electricity & $0.44 *(0.27)$ & $-0.05(0.06)$ & $-0.03(0.02)$ & $\begin{array}{l}0.002 \\
(0.004)\end{array}$ & $-3.30(6.26)$ & 0.41 & 21 \\
\hline PHCs with telephone & $-1.36 * *(0.62)$ & $0.49 * * *(0.14)$ & $0.20 * * *(0.06)$ & $\begin{array}{l}0.02^{*} \\
(0.009)\end{array}$ & $-3.72(15.93)$ & 0.74 & 22 \\
\hline PHCs with computer & $-1.01(0.74)$ & $0.63 * * *(0.17)$ & $0.23 * * *(0.07)$ & $0.04 * * *(0.01)$ & $-31.84 *(19.10)$ & 0.67 & 22 \\
\hline $\begin{array}{l}\text { PHCs with referral transport } \\
\text {. }\end{array}$ & $-0.61(1.04)$ & $0.38 *(0.23)$ & $0.12(0.10)$ & $0.01(0.02)$ & $-6.45(26.77)$ & 0.31 & 21 \\
\hline PHCs with labour rooms & $0.89(0.75)$ & $-0.03(0.17)$ & $0.07(0.07)$ & $0.003(0.01)$ & $26.92(19.43)$ & 0.41 & 22 \\
\hline PHCs with OT & $-1.06(0.91)$ & $0.09(0.21)$ & 0.17 ** $(0.08)$ & $0.0003(0.01)$ & $15.92(21.54)$ & 0.41 & 21 \\
\hline PHCs with 4 beds & $-1.33 *(0.88)$ & $-0.23(0.20)$ & $0.16 * *(0.08)$ & $-0.005(0.01)$ & $17.05(20.70)$ & 0.49 & 21 \\
\hline
\end{tabular}

*** $1 \%$ level significance, $* * 5 \%$ level significance, $* 10 \%$ level significance, Data in parenthesis show standard error.

TABLE IV: SUMMARY TABLE OF REGRESSION RESULTS ON INFRASTRUCTURE, DRINKING WATER AND SANITATION.

\begin{tabular}{|c|c|c|c|c|c|c|c|}
\hline \multirow[t]{2}{*}{ Dependent variables } & \multicolumn{7}{|c|}{ Independent variables } \\
\hline & Pop SC/ST & Income & Size km2 & Distance & Access to sea & $\mathrm{R}$-square & Obs. \\
\hline Road in $100 \mathrm{KM}$ & $-1.5(10.791)$ & $5.43 *(3.170)$ & $-0.8(1.017)$ & $-0.06(0.165)$ & $-175(278.5)$ & 0.43 & 21 \\
\hline Road per 100,000 populations & $1.86(5.492)$ & $1.46(1.613)$ & $0.31(0.517)$ & $0.15 *(0.084)$ & $-66.4(141.7)$ & 0.28 & 21 \\
\hline $\mathrm{NH}$ in $100 \mathrm{KM}$ & $-0.04(0.051)$ & $0.02(0.021)$ & $-0.009 *(0.005)$ & $0.0004(0.0008)$ & $-0.33(1.323)$ & 0.55 & 21 \\
\hline $\mathrm{NH}$ per 100,000 populations & $-0.39(0.470)$ & $0.02(0.140)$ & $-0.002(0.044)$ & $0.009(0.007)$ & $-6.5(12.129)$ & 0.27 & 21 \\
\hline Drinking water & $\begin{array}{l}-1.27 * * * \\
(0.348)\end{array}$ & $0.11(0.100)$ & $-0.06^{*}(0.033)$ & $-0.01 *(0.0053)$ & $3.9(8.95)$ & 0.77 & 22 \\
\hline Tap water & $-0.46(0.505)$ & $0.58 * * *(0.145)$ & $0.05(0.047)$ & $-0.0009(0.008)$ & $10.3(12.97)$ & 0.76 & 22 \\
\hline Improved drinking water & $-0.24(0.225)$ & $6.35 \mathrm{E}(8.76 \mathrm{E})$ & $-0.02(0.044)$ & $-0.006(0.006)$ & $6.01(11.547)$ & 0.40 & 17 \\
\hline No latrine & $0.84 *(0.427)$ & $-0.21 *(0.125)$ & $0.05(0.040)$ & $0.002(0.007)$ & $-2.8(11.01)$ & 0.69 & 21 \\
\hline
\end{tabular}

$* * * 1 \%$ level significance, $* * 5 \%$ level significance, $* 10 \%$ level significance, Data in parenthesis show standard error.

\section{CONCLUSION}

Given wide spread caste discrimination against SCs and STs in modern India, anti-discrimination and reservation policies are essential. However, more or at least equal provision of public goods for SC/ST may play significant role in bridging the development gap, as large gap between $\mathrm{SC} / \mathrm{ST}$ and non-SC/ST is due to differences in human capital endowment [116]. Present paper is limited to public goods in education and health. Therefore other public goods (like general cleanliness, drainage and waste disposal, play area for children near house premises, availability of electricity for domestic use, supply and consumption of Iodised salt, availability of post office, police station and number of police personnel) may be interesting variables for future study. Further, the district, sub-district and village level studies may shed more light on the subject.

\section{Appendix}

TABLE V: DESCRIPTION OF DEPENDENT VARIABLES, ON EXPENDITURE ON EDUCATION AND HEALTH.

\begin{tabular}{|l|l|}
\hline Dependent variables & Description \\
\hline Education & $\begin{array}{l}\text { State-wise expenditure on education as \% } \\
\text { of total public expenditure of state }\end{array}$ \\
\hline $\begin{array}{l}\text { Exp. as \% of total } \\
\text { exp. }\end{array}$
\end{tabular}

\begin{tabular}{|l|l|}
\hline Exp. as \% of SGDP & $\begin{array}{l}\text { State-wise expenditure on education as \% } \\
\text { of state GDP }\end{array}$ \\
\hline Per person exp. & $\begin{array}{l}\text { State-wise total expenditure on education } \\
\text { divided by total population between age 6- } \\
24 .\end{array}$ \\
\hline Per student exp. & $\begin{array}{l}\text { State-wise total expenditure on education } \\
\text { divided by population between age 6-24, } \\
\text { enrolled in educational institutions. }\end{array}$ \\
\hline Health & $\begin{array}{l}\text { State-wise expenditure on health as \% of } \\
\text { total public expenditure of state. }\end{array}$ \\
\hline $\begin{array}{l}\text { Exp. as \% of total } \\
\text { exp. }\end{array}$ & $\begin{array}{l}\text { Total expenditure on health as \% of state } \\
\text { GDP. }\end{array}$ \\
\hline Exp. as \% of SGDP \\
\hline Per person exp. & $\begin{array}{l}\text { State-wise total expenditure on health } \\
\text { divided by total population. }\end{array}$ \\
\hline
\end{tabular}

TABLE VI: DESCRIPTIVE STATISTICS OF DEPENDENT VARIABLES ON EXPENDITURE ON EDUCATION AND HEALTH BY STATES.

\begin{tabular}{|l|l|l|l|l|l|l|}
\hline \multirow{2}{*}{$\begin{array}{l}\text { Independe } \\
\text { nt } \\
\text { variables }\end{array}$} & \multicolumn{6}{|l|}{ Descriptive statistics } \\
\cline { 2 - 7 } & Mean & $\begin{array}{l}\text { Media } \\
\mathrm{n}\end{array}$ & Min. & Max. & $\begin{array}{l}\text { Std. } \\
\text { Dev. }\end{array}$ & $\begin{array}{l}\text { Obs } \\
.\end{array}$ \\
\hline Public expenditure on education \\
\hline $\begin{array}{l}\text { Exp. as \% } \\
\text { of total } \\
\text { exp. }\end{array}$ & 20.30 & 22.51 & 0.44 & 26.08 & 6.59 & 22 \\
\hline $\begin{array}{l}\text { Exp. as \% } \\
\text { of SGDP }\end{array}$ & 3.25 & 3.07 & 0.03 & 7.02 & 1.57 & 22 \\
\hline Per person & 644.00 & 525.53 & 94.59 & 3051.4 & 578.4 & 22 \\
\hline
\end{tabular}




\begin{tabular}{|l|l|l|l|l|l|l|}
\hline exp. & & & & 9 & 5 & \\
\hline $\begin{array}{l}\text { Per } \\
\text { student } \\
\text { exp. }\end{array}$ & 741.08 & 638.70 & $\begin{array}{l}108.2 \\
2\end{array}$ & $\begin{array}{l}3332.4 \\
4\end{array}$ & $\begin{array}{l}621.0 \\
8\end{array}$ & 22 \\
\hline Public expenditure on health & & & & & \\
\hline $\begin{array}{l}\text { Exp. as \% } \\
\text { of total } \\
\text { exp. }\end{array}$ & 5.00 & 4.75 & 3.6 & 9.6 & 1.31 & 20 \\
\hline $\begin{array}{l}\text { Exp. as \% } \\
\text { of SGDP }\end{array}$ & 0.96 & 0.83 & 0.49 & 4.00 & 0.70 & 22 \\
\hline $\begin{array}{l}\text { Per person } \\
\text { exp. }\end{array}$ & 905.05 & 665.50 & $\begin{array}{l}257.0 \\
0\end{array}$ & $\begin{array}{l}3849.0 \\
0\end{array}$ & $\begin{array}{l}803.1 \\
8\end{array}$ & 22 \\
\hline
\end{tabular}

[18] S. Thoral and C. Senapati, "Employment and unemployment situation: Rural and Urban," in Bridging the social gap: Perspective on Dalit Empowerment, S. Thorat and N. S. Sabharwal, Ed. New Delhi: Rawat Publications, 2014, Ch. 12, pp. 214-247.

[19] I. P. Desai, "Caste and family," Economic Weekly, vol. 6, pp. 249-254, Feb., 1954.

[20] A. Banerjee, E. Duflo, M. Ghatak, and J. Lafortune, "Marry for what? Caste and mate selection in modern India," American Economic Journal: Macroeconomics, vol. 1, no. 2, pp. 33-72, May 2013.

[21] A. Behar and Y. Kumar, "Decentralisation in Madhya Pradesh, India: from Panchayati Raj to gram Swaraj (1995 to 2001)," Overseas Development Institute, vol. 5, no. 2, pp. 15-45, Oct. 2002.

[22] G. Mathew, "Panchayat Raj Institutions and human rights in India," Economic and Political Weekly, pp. 155-162, Jan.11, 2003.

[23] J. P. Mangubhai, A. Irudayam and E. Sydenham, Dalit Women's Right to Political Participation in Rural Panchayat Raj- A study of Women in Gujarat and Tamil Nadu, IDEAS Justitia et (Equal in Right), Madurai, 2009, Ch. 6.

\section{REFERENCES}

[1] A. Sen, "Why India will never be a superpower," Outlook, Nov. 21, 2015.

[2] W. Easterly and R. Levine, "Africa's growth tragedy: Policies and ethnic divisions," The quarterly Journal of Economics, no. 4, pp. 1203-1250, November, 1997.

[3] A. Alesina, R. Baqir, and W. Easterly, "Public goods and ethnic divisions," NBER. Working paper no. W6009. 1997.

[4] The Government of India, the Ministry of Law and justice, Legislative department "The Constitution of India," 2011. pp. 22-28, 124-156.

[5] J. Dreze and A. Goyal, "Future of mid-day meals," Economic and Political Weekly, vol. 1, pp. 4673-4683, Nov., 2003.

[6] S. Thorat and J. Lee, "Food security schemes and caste discrimination," in Blocked by caste: Economic discrimination in Modern India, S. Thorat and N. Katherine, Ed. New Delhi: Oxford University Press, 2010, Ch. 3 pp. 271-298.

[7] G. B. Namabissan, "Exclusion and discrimination in schools: Experiences of Dalit children," in Blocked by Caste: Economic Discrimination in Modern India, S. Thorat and N. Katherine, Ed. New Delhi: Oxford University Press, 2010, Ch. 3 pp. 246-270.

[8] S. Desai, C. D. Adams, and A. Dubey, "Segmented schooling: inequalities in primary education," in Blocked by Caste: Economic Discrimination in Modern India, S. Thorat and N. Katherine, Ed. New Delhi: Oxford University Press, 2010, Ch. 3 pp. 230-245.

[9] V. Borooah. (2010). Inequality in health outcomes in India: the role of caste and religion. [Online]. Available: https://scholar.google.co.uk/scholar?Hl=en\&q=inequality+in+health+ outcomes+in+india+\&btng=\&as_sdt=1\%2C5\&as_sdtp.

[10] S. Acharya, "Caste and pattern of discrimination in rural public health care services," in Blocked by Caste: Economic Discrimination in Modern India, S. Thorat and N. Katherine, Ed. New Delhi: Oxford University Press, 2010, Ch. 3 pp. 208-229.

[11] S. George. (2015). Caste and Care: Is Indian Healthcare Delivery System Favourable for Dalits? [Online]. Available: https://scholar.google.co.uk/scholar?Hl=en\&q=CASTE+AND+CAR E\%3A+IS+INDIAN+HEALTHCARE+DELIVERY+SYSTEM+FAV OURABLE+FOR+DALITS $\% 3 \mathrm{~F}+\& \mathrm{btng}=\&$ as_sdt=1\%2C5\&as_sdtp

[12] S. Anderson, (2005). Some economic implications of caste. [Online]. Available:

https://scholar.google.co.in/scholar?q=anderson+2005+caste\&btnG= \&hl=en\&as_sdt $=0 \% 2 \mathrm{C} 5$

[13] A. Singh. (2010). Does return to farming depend on caste? New evidence from India. [Online]. Available: https://scholar.google.co.in/scholar?q=Does+return+to+farming+depe nd+on+caste $\% 3 F+$ Singh\&btnG $=\& h l=e n \& a s \_s d t=0 \% 2 C 5$

[14] NSS $68^{\text {th }}$ round, "Employment and Unemployment situation among social groups in India," The Government of India, Ministry of Statistics and Programme implementation, report no. 563, Jan. 2015

[15] S. Thorat, M. Mahamallik, and N. sadana, "Caste system and pattern of discrimination in Rural markets," in Blocked by Caste: Economic Discrimination in Modern India, S. Thorat and N. Katherine, Ed. New Delhi: Oxford University Press, 2010, Ch. 2 pp. 148-176.

[16] S. Madheswaran, "Caste discrimination in the Indian urban labour market: An econometric analysis," Rivista Internazionale di Scienze Economiche e Commerciali, vol. 53, no. 3, pp. 349-372, Sep. 2006.

[17] S. Thorat and P. Attewell, "The legacy of social exclusion: A correspondence study of job discrimination in India," Economic and political weekly, pp. 4141-4145, Oct. 13, 2007.

[24] Census of India. The Government of India- Ministry of home affairs Primary Census Abstract. [Online]. Available: http://www.censusindia.gov.in/2011census/hlo/HLO_Tables.html

[25] Ministry of human resource development, The Government of India, Analysis of budgeted expenditure on education 2011-12 to 2013-14 [Online].

Available: http://mhrd.gov.in/sites/upload_files/mhrd/files/statistics/ABE_201114.pdf

[26] Central Bureau of health intelligence, The Government of IndiaMinistry of health and family welfare, National health profile 2015 [Online]. Available: http://cbhidghs.nic.in/

[27] National council of educational research and training, $7^{\text {th }}$ all India school education survey, 2009-10. [Online]. Available: http://www.ncert.nic.in/programmes/education_survey/index_educati on.html

[28] National university of educational planning and administration (NUEPA) U-DISE. [Online]. Available: http://schoolreportcards.in/SRC-New/

[29] National family health survey, Ministry of health and family welfare, NFHS-4. [Online]. Available: http://rchiips.org/nfhs/about.shtml

[30] National health mission, Ministry of health and family welfare, rural health statistics. [Online]. Available: https://nrhmmis.nic.in/SitePages/HMIS-

Publications.aspx?RootFolder=\%2FPubStatistical_Publications\%2FR ural $\% 20$ Health $\% 20$ Statistics\&FolderCTID $=0$ x012000AC878C9A74 E6DC46A4B9220C1AAC27300098F49E13CE4ED442AB009F0A97 E0CFFA\&View $=\{963874 F 4-C 1 D D-4335-9 E E B-C 1 F C 961508 F B\}$

[31] National highways authority of India, Ministry of road transport and highways, India road networks. [Online]. Available: http://www.indiaenvironmentportal.org.in/files/file/basic\%20road\%2 0statistics\%20of\%20india.pdf

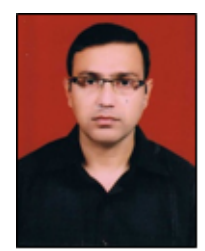

Raghunath Prasad Saket was born in 1980. He is assistant professor of economics, in Satyawati College (University of Delhi), India. In 2015, he was awarded the fellowship by the University of Delhi, to take training in finance and economic development, at the University of Glasgow, UK, to enhance the educational standard in India in concerned field. Publications:

1. R. P. Saket, "Dr. Ambedkar's view on Social Justice: Challenges," World Focus, Vol. XXXIV, No. 4, pp. 29-31, June, 2013

2. R. P. Saket, "Gender Exclusion, Discrimination and Deprivation of Women in India", in Social Problems in India, B. Sonber and R. Usrethe, Ed. Manav Nirman Sansthan, Chhisgarh, 2012, Ch. 4 pp. 74-91

3. S. Karakoti and R. P. Saket, "Caste oppression, Economic Discrimination and poverty among Scheduled Castes in India," in Exclusion and Discrimination: Concepts, Perspectives and Challenges, Y. C. Rao and S. Karakoti, Ed. Rawat Publications, India, 2010, Ch. 8 pp. 81-98.

Research Field: Social Exclusion, discrimination against historically deprives groups; and on-going discrimination against them in the process development.

Mr. Saket is member of IEDRC (member no. 90081011). And also member of review committee for ICHC 2017. 